\title{
Engaging the Nonprofit Sector to Ensure Social Justice in Local Housing Marketplaces
}

\author{
Joshua Odetunde \\ Walden University
}

\begin{abstract}
The essay attempts to fill the gaps found in knowledge and practice for conceptualizing local housing marketplaces in public policy administration. Dichotomous conceptualization in terms of homeownership and rental housing led to inefficient local housing marketplaces and affordability issues. The rationally evolving economic concept of local housing marketplaces is to financially leverage every family and stimulate investing in landed properties for decent homes. Hence, the Housing Act of 1949 reasonably envisaged every American family having access to a decent home as the great equalizer. Social change to rational conceptualization of local housing marketplace would help resolve affordability issues. Then, complementary civic engagement through community-based nonprofit real estate management programs highlighted could ensure social justice.
\end{abstract}

Keywords: housing, nonprofit, social justice, real estate management, community

\section{Introduction}

Families were used to assisting one another to have homes in their communities because housing is a basic need. Like a capital resource, every family needs a home to live and work in the community irrespective of the size of household income. Every city or community is a unique local housing marketplace distinct from the national context of a housing market. The communal arrangements evolved into using home mortgage loan as financial leverage to become a homeowner in various local housing marketplaces in the United States (Integrated Financial Engineering, 2006). The financial engineering of the housing industry stimulated savings and loan associations to become a strong economic force in the 20th century (Mason, 2010). The evolution is economically rational in practice, but it creates "unsettling gaps" (MacLennan, 2012, p. 6) in knowledge for conceptualizing local housing marketplaces. Based on the knowledge of various subsidy programs for low-income households to close the unsettling gaps in the nonprofit sector, Vidal (2002) had conceptualized local housing marketplaces as comprising market-rate and subsidized housing units. In a case study research, Odetunde (2015) identified the unsettling gaps as dichotomous conceptualization in terms of rental homes and homeownership. While the rational evolving economic concept is to stimulate savings and investments for homes in local housing marketplaces, it is not as obvious in practice for public policy administration.

Nevertheless, the financial engineering of the housing industry reasonably became public policy when it was reinforced and solidified with government-sponsored enterprise Fannie Mae in 1938 to boost the secondary market in residential mortgages. The goal was that every American family would have a decent home as soon as feasible in the Housing Act of 1949. The goal is in line with the universal human right declaration of the previous year. The public policy was again reinforced in

I wish to acknowledge with profound gratitude the contributions of Dr. Ken C. Sherman, who helped to make the article meaningful and readable. 
1970 with another government-sponsored enterprise, Freddie Mac. Despite the public policy to financially engineer the housing industry for helping every family gain access into local housing marketplaces, many people are still homeless or still occupy inadequate housing across the United States. At the same time, several residential properties are vacant or abandoned in declining neighborhoods as foreclosures for default on home mortgage loans remain perennial challenges in various cities (Odetunde 2015). Public policy administration in the housing market has not clearly evolved into a financial system for stimulating investment in landed properties for homes and for helping families to conceptualize their local housing marketplaces as such.

\section{Local Housing Marketplaces}

While the purpose of public policy administration, based on the economic evolution, should be to stimulate investing in landed property to meet housing needs in local housing marketplaces, it is still not as obvious in practice. Despite various financial incentives such as home mortgage interest tax deductions and other programs for homeowners, landed property rights in rental housing are still being confused with homeownership in local housing marketplaces. The misconceptions are compounded because public policy administration had shifted towards rental homes in 1937, during the great depression, when low-income households were living mostly in substandard housing units (Edson, 2011; Stoloff, 2004). Ironically, while landed property rights remain indispensable to meet housing needs, the common concern for real property rights became less obvious with the shift toward rental homes. Also, while rental housing remains a home of choice for a cross-section of American families, it became a home of "necessity for millions of low-income households" (Alexander et al., 2011, p. 1). Real estate management professionals who could counsel individual families on how to meet housing needs and help in navigating local housing marketplaces are more focused on commercial aspects of the profession.

Thus, low-income American families are not sharing the mutual benefit of public policy in their local housing marketplaces. The goal of a decent affordable home as a capital resource for every American family became unattainable in local housing marketplaces. To acquire decent, affordable housing became more difficult because subsidies are commonly tied to periodic incomes of households, shifting attention away from leveraging homeownership investments as capital resource need of every household. It now requires the nonprofit sector complementing the public policy in local housing marketplaces to ensure social justice in terms of that goal. Because housing is a basic need, every family should be financially leveraged to invest in homeownership irrespective of income level. Like capital resources, homeownership provides the means of increasing net worth to secure some measure of financial security or independence for many families.

Every family, irrespective of income level, deserves some financial leverage for homeownership not to become the engine driving income inequality. The most valuable assets of many American families are their homes (Byrne \& Diamond, 2006). Excluding low-income families from homeownership becomes the avenue for exploitative practices in local housing marketplaces. The poorest families are inadvertently restricted to undesirable environments with inadequate housing (Rider, 2016; Viard, 2017). The American dream of homeownership should not become morbid desires among low-income families to keep them perpetually dependent on public subsidies for standard living conditions. Lowincome families need community-based nonprofit real estate management. If they are being subsidized to rent, they can collaborate to build, preserve, and market equitable values in their landed properties in the form of homeownership or capital assets. It should immediately be distinguished from unionizing or consumer association. It is collaboration to tap into the mutual benefits of public policy. 
Promoting inclusive homeownership does not preclude commercial activities and rental housing in local housing marketplaces. Like homeownership, rental housing should be accessible for various short-term leases irrespective of income levels. Besides, low-income households can be leveraged indirectly through various leasehold arrangements. American families could make various forms of leasehold arrangements among them to meet their housing needs as the dynamic economic and social environment demands beyond the scope of commercial activities. An inclusive homeownership community would synchronize the housing needs of American families with the trajectory of local housing marketplaces in terms of supply and demand. The goal is not to supplant profit incentives in the housing industry, but to channel those incentives for mutual benefit in terms of accessibility and improved living conditions in local housing marketplaces. Public housing in the United States is not a generic concept in terms of public assistance because the housing market is a private sector.

The current dichotomous conceptualization of local housing marketplaces comprising market-rate and subsidized housing units is rooted in historical public intervention in rental housing to address critical environmental housing needs of low-income families in the United States. Therefore, generic use in terms of public assistance still influences most public policy regulations or guidelines because of dichotomous conceptualization of local housing marketplaces. Rather than being active investors in their local housing marketplaces like others, low-income households are inadvertently grouped with vulnerable population as beneficiaries of charitable rental subsidy programs (Fischer \& Sard, 2017). In some cases, low-income families who obtained mortgage loans with down-payment assistance in their local housing marketplaces eventually lost their homes to foreclosure. This was because they did not have real estate management counseling or social support for building, preserving, and marketing equitable values in their landed properties before the housing market crisis. That is, low-income households are largely excluded from improving their living conditions in their local housing marketplaces unless they attain an unspecified income level.

\section{Affordable Housing}

To ensure social justice and mutually beneficial affordable housing, decent homes as investment units must be equitably distributed among the households in a local housing marketplace. The housing needs of low-income families do not differ from others in terms of standard qualities, basic amenities, and advantages (Bach et al., 2007). Affordability issues arose because rental housing is confused with homeownership in public policy administration. The rational financial concept in economics is to make local housing marketplaces accessible to every household through leveraging by mortgage loans. Thus, Kalugina (2016) rightly concluded that "addressing the lack of affordable housing in the United States requires long-term thinking, political determination, and behavioral changes" (p. 83). Recurrent instability in the housing market due to a high rate of foreclosures shows the issue is not affordability in terms of the need for new constructions. In other words, the current waste and inefficiency in the form of houses left vacant and abandoned while some families are homeless or occupying inadequate houses across the United States are evidence that affordability per se is not the issue.

Housing affordability is not a development cost issue but a marketing issue. The issue is how to equitably distribute or market the mutual benefits of leveraging homeownership as an investment and the great equalizer among households in the local housing marketplaces. The housing needs of American families must be synchronized with the trajectory of local housing marketplaces in terms of supply and demand. That is, low-income families must also be empowered as investors in their local housing marketplaces. Their empowerment would require innovative civic engagement by related nonprofit sector institutions to complement public policy in local housing marketplaces. The 
social change in marketing could take the form of voluntary network of existing and prospective homeowners collaborating as investors, irrespective of income levels.

Low-income families need such collaboration to ensure they can also hold and control the equitable values of their landed properties as mutual benefits. Although people tend to see a house as a valuable personal asset, its value resides in the community in terms of supply and demand by households. Besides, the value is inextricably interwoven with land-use patterns, planning and zoning regulations, public policies, public utility regulations, the design and structure of the house itself, construction costs, building materials, neighborhood tone, and several other local and national factors. Therefore, an efficient local housing marketplace with the slight problem of foreclosures resulting in vacant or abandoned housing units requires cross-sector collaborations. A nonprofit agency could organize households as a network of active participants to protect equitable values of their housing units. At the same time, the agency could ensure that community housing needs are normally met through the market.

While every family could actively participate, the social change leadership requires some knowledge of real estate management and the nonprofit sector. The professional knowledge is needed to harness the invaluable mutual benefits of collaborating to help one another to have a decent home with some measure of financial security through investing in local housing marketplaces. Every family can be involved because rent or a monthly mortgage payment is the largest expense item for many families. It is the rational economic evolution of local housing marketplaces, though public policy has not evolved the same way due to inconsistent implementations. Nevertheless, families collaborating with one another as homeowners or investors in various communities remains consistent with public policy.

\section{Nonprofit Housing Assistance Programs}

The focus of charitable nonprofit housing assistance is to make the mutual benefit of equitable values accessible to every household because residential landed property investments are commonly leveraged. The focus is not to supplant the profit incentives needed for qualitative production in the housing industry. Conceptual understanding of the economy and nonprofit sector is not all about market failure in terms of demand and supply for charitable assistance (Odetunde, 2016). The assistance low-income households need in local housing marketplaces is to hold their equitable values in landed properties while their periodic investments are being leveraged like others. Local housing marketplaces are primarily for private properties. That is, most of the houses are private properties though investments in those houses are leveraged to stimulate individual contributions.

Therefore, housing assistance would involve direct civic engagement because holding and managing equitable values of landed properties requires professional knowledge. It is the essence of real estate management profession. Every household pays directly or indirectly for real estate management in local housing marketplaces. A homeowner must manage the four dimensions of "land tenure, land value, land use, and land development" (Enemark, 2009, p. 1). For example, inadequate management of equitable values results in poor maintenance, abusive uses, abandoning properties, and foreclosures. Property management is not just tenant selection or maintenance of the physical structure and environment. It includes managing the leveraged financial investments to maintain valuable use of the physical structure. Thus, common interest communities such as neighborhood associations, condominiums, and cooperative housing emerge in local housing marketplaces to protect property values. Despite those imperative features to ensure real estate management in local housing marketplaces, local governments still have departments for property maintenance and code 
enforcement. It is public policy to discourage absentee landlords because the community pays directly or indirectly for inadequate real estate management.

In view of the dichotomous conceptualization, nonprofit housing assistance programs in local housing marketplaces revolve around four distinct aspects of community-based real estate management programs to complement public policy administration. First, there is a need for research, education, and advocacy because of the longstanding dichotomous conceptualization of local housing marketplaces in terms of rental homes and homeownership. Secondly, there should be demonstrable evidence that every family can transition from homelessness to permanent housing in the form of a rehabilitation and prevention program. Third, there must be demonstrable evidence that community-based nonprofit real estate management is sustainable for making local housing marketplaces accessible and efficient. Fourth, it should be possible to juxtapose low-income families as homeowners in various neighborhoods of the community through collaboration to resolve the issue of affordability. Some existing housing-related nonprofit organizations illustrate these programmatic aspects of community-based nonprofit real estate management for complementing public policy administration.

\section{Housing Needs Research and Advocacy Program}

Metropolitan Housing Coalition in Louisville, Kentucky, promotes fair and affordable housing through research, education, and advocacy. The legislative advocacy effort led to establishing the Affordable Housing Trust Fund for Louisville and Kentucky State. It also led to creating a homeownership funding source for individual development accounts as well as alternative development incentives in the Louisville-Jefferson County Land Development Code. However, dichotomous conceptualization of local housing marketplaces comprising market-rate and subsidized housing units or homeowners and renters still dominate most research works. Conceptualizing local housing marketplaces as opportunities for landed property investment comprising homeowners and various leasehold arrangements is not the same as thinking in terms of commercial buying and selling. Education, information, and experience are still needed for social change.

To connect research efforts with community-based nonprofit real estate management requires direct participation of beneficiaries. For example, research has found that low-income families benefit from living in mixed-income developments and neighborhoods with diverse income levels even with minimal effects of social interactions (Levy, McDade, \& Dumlao, 2010). Yet, charitable social services programs for rehabilitating the vulnerable population and low-income households are still disconnected from their housing needs in local housing marketplaces. Low-Income Housing Tax Credit programs are still struggling to avoid segregated housing patterns (Rider, 2016). The case of Texas Department of Housing and Community Affairs v. Inclusive Communities Project, Inc. (2015) is illustrative. Housing programs under Section 8 of the Housing Act of 1937 struggled with the similar issue before evolving into Housing Choice Vouchers in the Housing and Community Development Act of 1974 .

Fair housing laws at federal, state, and local government levels prohibit discrimination based on race, color, religion, sex, handicap, national origin, or even familial status. It is not reasonable to prohibit discrimination based on income levels in a free market economy. Fortunately, homeownership is to be the great equalizer, not the engine for driving inequality. The essence of housing needs research program is to inform innovation and adaptation of housing supply as the society changes and living conditions improve, rather than conceptualizing local housing marketplaces in terms of discrete supply and demand. 
To connect education and advocacy with community-based nonprofit real estate management requires focusing on how to help families build, preserve, and market their home equities. Individual development accounts are still based on the dichotomous concept of local housing marketplaces. While such programs could stimulate middle-income households to save for homeownership, lowincome households may not gain access into the local housing marketplace through it. Education and advocacy in community-based nonprofit real estate management are based on understanding the mutual benefits of stimulating families to invest in residential properties by using mortgage loan and other homeowner financial incentives as leverage. Families could then freely share the mutual benefits among them equitably, as they are given equal access to invest in residential landed properties.

\section{Homeless Rehabilitation and Prevention Housing Program}

Coalition for the Homeless in Louisville illustrates this program dimension of community-based nonprofit real estate management. The mission of the organization is to advocate for people who are homeless in general and find ways to prevent and eliminate homelessness. To achieve the mission, the nonprofit organization educates and inspires the community to act, advocate for systemic changes in the community, and coordinate community resources and funding for charitable housing of the homeless. The agency develops community-based blueprints to prevent and end homelessness. The current blueprint is from 2015 to 2020 . The agency also developed a continuum of care program to connect various charitable social services support for the homeless people.

The 5-year blueprints have been renewed many times without ending homelessness because of dichotomous conceptualization of local housing marketplaces. The goal of housing every American family cannot be attained unless every family, irrespective of income level, could be financially leveraged to change social status from homelessness to homeownership. There must be demonstrable evidence that families can be rehabilitated from homelessness. Similarly, there must be demonstrable evidence that families are prevented from falling into homelessness. Many of the existing charitable shelters for the homeless people are mainly dealing with symptoms because beneficiaries are not directly involved. Homeless families are not given access to invest in places to live and work. The prevalent reasoning is that families are working to find worthwhile places to live. Many American families are not fully aware of their real property rights for housing. Proper conceptualization of local housing marketplaces is enabling families with housing as capital resources for productivity and improved living conditions. Every family should be financially leveraged to have a decent home.

The implications from the foregoing is not that rehabilitating homeless people costs less. The emphasis is to integrate other social services with housing needs of families. Currently, those social services are not necessarily integrated as part of the support system for housing. Therefore, transitional housing with supportive social services by charitable nonprofit organizations is not linked to local housing marketplaces to rehabilitate their beneficiaries. Homeless rehabilitation housing program could fill the gap through networking and collaboration with existing shelters for the homeless.

Furthermore, helping to prevent individuals from becoming homeless requires reciprocal response from beneficiaries. Individuals are personally responsible to take advantage of mutual benefits provided by the community. Taking advantage of mutual benefits implies that the individual is also willing to contribute directly or indirectly to those mutual benefits. Helping individuals to develop a responsible sense of community belonging is as important as creating awareness of the mutual benefits. Thus, local nonprofit organizations are uniquely suitable to evolve various innovative 
strategies for preventing homelessness as opposed to creating another entitlement or public housing program through top-down approach to complementing housing policy. Homeless prevention program can be linked with sweat equity contributions, job training, housing counseling and monetary management workshops, volunteer services and others personal involvements to enhance community participation for mutual benefits. The program can also involve application for selecting active participants as beneficiaries.

\section{Community-Based Nonprofit Real Estate Management Program}

Ideally, the key role of Louisville Metro Housing Authority (LMHA) should be community-based nonprofit real estate management to ensure social justice by giving families equal opportunity to invest in the local housing marketplace, irrespective of income level. However, the agency cannot work directly with individual family in the local housing marketplace because it is public agency, though it is also an independent nonprofit agency (Odetunde, 2015). The establishment is based on dichotomous concept of local housing marketplaces. The current mission of LMHA is to "provide quality, affordable housing for those in need, assist residents in their efforts to achieve financial independence, and work with the community to strengthen neighborhood" (LMHA, 2017, para. 1). While the mission is obviously to ensure social justice, the programs do not connect the other three aspects of community-based nonprofit real estate management because of the dichotomous conceptualization of local housing marketplaces.

The focus of community-based nonprofit real estate management is to promote homeownership as capital resource investments through collaboration in building, preserving, and marketing of equitable values in landed properties. There is a broad spectrum of housing needs for families to freely share the mutual benefits of homeownership through leasehold arrangements. In an efficient local housing marketplace, residential property would be mutually beneficial to the homeowner as investor and the lessee as direct beneficiary or user. Community-based nonprofit real estate management is the intersection of public and private interests in landed properties. Unlike, the current sharp division between public and private interests in dichotomous conceptualization of local housing marketplaces, public intervention could take the form of a nonprofit real estate management Company with portfolios of single family homes, apartments, and condominiums. Because financial investments are commonly leveraged, the essence of institutionalized community-based program is to make local housing marketplaces efficient and equally accessible without depressing market value of landed properties. Helping low-income households to collaborate in sharing the mutual benefits of public policy is essential for efficient local housing marketplaces to ensure social justice.

\section{Low-Income Homeownership Program}

The Fuller Center for Housing is an example of nonprofit organization that focuses on the ultimate public purpose of eradicating housing poverty since housing is the first basic need to live and work in any community. The strategy of the organization is to partner "with individuals and community groups to build and rehabilitate homes for people in need" (Fuller Center for Housing, 2017, para. 2). The policy of the organization is to assist financially without interest or profit motive. Sweat equity contributions of beneficiaries are encouraged. Its successful projects in Louisville show that lowincome families can be juxtaposed as homeowners in various neighborhoods. They have low-income homeowners paying much less than the prevailing monthly average mortgage payment in the neighborhood. The target population of the organization is $20 \%$ to $50 \%$ of area median income.

However, the effort of the organization is disconnected from community-based nonprofit real estate management because of dichotomous conceptualization of local housing marketplace. The 
organization remains Louisville's best kept secret for low-income households. To connect with the other three aspects of community-based real estate management requires coordination. Without coordinating the four aspects of community-based nonprofit real estate management, the goal of eradicating housing poverty cannot be achieved. While coordination does not imply bringing all these organizations under one umbrella, it does imply identifying how they can collaborate and cooperate to achieve the common goal of housing low-income households to ensure social justice.

\section{Conclusion}

Houses have always been built through various communal arrangements. People were used to helping one another. Hence, savings-and-loan associations became a strong economic force for home mortgage loans as far back as the 20th century in the United States. Today, it has become part of the normal structure of the economy. However, the financial engineering of the housing industry in a capitalist economy is dominated by mainstream thinking that often views resources as limited for maximizing personal benefits. This mainstream economic thinking about a free market may be preventing the recognition of mutual benefits in the communal arrangements. Without institutionalized charitable social support as an economic force in the housing industry, the mutual benefits would remain untapped. Homeownership could remain a driving force for income inequality. Low-income families would remain constrained by the economic structure from having decent homes in their communities. Their equal importance as productive workforces in economic development would remain undermined. The Housing Act of 1949 reasonably envisaged every American family having access to a decent home with some measure of financial security and independence. It is now feasible for low-income households to collaborate as investors in their local housing marketplaces through community-based nonprofit real estate management to complement the public policy. This is the social change needed to make housing affordable.

\section{References}

Alexander, B., Baker, K., Baldwin, P., Belsky, E., Carliner, M., Chen, Y. . . W Will, A. (2011). America's rental housing: Meeting challenges, building on opportunities. Cambridge, MA: Joint Center for Housing Studies of Harvard University. Retrieved from http://www.jchs.harvard.edu/sites/jchs.harvard.edu/files/americasrentalhousing-2011.pdf

Bach, A., Gupta, P. K., Haughey, R., Kelly, G., Pawlukiewicz, M., \& Pitchford, M. (2007). Ten principles for developing affordable housing. Washington, DC: Urban Land Institute.

Byrne, J. P., \& Diamond, M. (2006). Affordable housing, land tenure, and urban policy: The matrix revealed. Fordham Urban Law Journal, 34, 527-612.

Edson, C. L. (2011). Affordable housing: An intimate history. In T. Iglesias \& R. E. Lento (Eds.), Guide to affordable housing developments (pp. 3-20). Chicago, IL: American Bar Association.

Enemark, S. (2009, June). Managing rights, restrictions and responsibilities in land. Paper presented at GSDI-11 World Conference, Rotterdam, The Netherlands. Retrieved from http://vbn.aau.dk/ws/files/18418349/Enemark.pdf

Fischer, W., \& Sard, B. (2017). Tilt toward well-off homeowners leave struggling low-income renters without help. Retrieved from https://www.cbpp.org/sites/default/files/atoms/files/12-1813hous.pdf

Fuller Center for Housing. (2017). Mission statement, principles and FQAs: What is the Fuller Center for housing? Retrieved from https://fullercenter.org/mission-statement/

Integrated Financial Engineering, Inc. (2006). Evolution of the U.S. housing finance system: A historical survey and lessons for emerging mortgage market. Washington DC: U.S. 
Department of Housing and Urban Development. Retrieved from https://www.huduser.gov/portal/publications/pdf/US_evolution.pdf

Kalugina, A. (2016). Affordable housing policies: An overview. Cornell Real Estate Review, 14, 76-83. Retrieved from http://scholarship.sha.cornell.edu/crer/vol14/iss1/10

Levy, D. K., McDade, Z., \& Dumlao, K. (2010). Effects from living in mixed-income communities for low-income families: A review from literature. Retrieved from https://www.urban.org/sites/default/files/publication/27116/412292-Effects-from-Living-inMixed-Income-Communities-for-Low-Income-Families.PDF

Louisville Metro Housing Authority (LMHA). (2017). Our mission. Retrieved from www.lmha1.org

MacLennan, D. (2012). Understanding housing markets: Real progress or stalled agendas? In D. F. Clapham, W. A. V. Clark, \& K. Gibb (Eds.), The sage handbook of housing (pp. 5-26). Thousand Oaks, CA: Sage.

Mason, D. L. (2010). Homeownership is colorblind: The role of African-American savings and loans in home finance, 1880-1980. Business and Economic History On-line, 8, 1-8.

Odetunde, J. O. (2015). Engaging the nonprofits in Louisville housing market for low-income households. Walden dissertations and doctoral studies. Retrieved from http://scholarworks.waldenu.edu/cgi/viewcontent.cgi?article=2652\&context=dissertations

Odetunde, J. O. (2016). Economy and nonprofit sector. In A. Farazmand (Ed.), Global encyclopedia of public administration, public policy, and governance (pp. 1-8). Basel, Switzerland: Springer International. http://dx.doi.org/10.1007/978-3-319-31816-5_2703-2

Rider, J. W. (2016). Internal Revenue Service Bulletin 2016-77. Retrieved from https://www.irs.gov/pub/irs-irbs/irb16-12.pdf

Stoloff, J. A. (2004). A brief history of public housing. Retrieved from https://www.researchgate.net/profile/Jennifer_Stoloff/publication/228789405_A_brief_history _of_public_housing/links/5643a68008ae9f9c13e05df6/A-brief-history-of-public-housing.pdf

Texas Department of Housing and Community Affairs v. Inclusive Communities Project, Inc. (2015). 576 U.S. Retrieved from https://www.oyez.org/cases/2014/13-1371

Viard, A. D. (2017). Low income housing tax credits and the concentration of poverty. Retrieved from http://nlihc.org/sites/default/files/AG-2017/2017AG_Ch05-S09_Low-Income-Housing-TaxCredits_LITEC.pdf

Vidal, A. C. (2002). Housing and community development. In L. M. Salamon (Ed.), The state of nonprofit America (pp. 219-239). Washington, DC: Brookings Institution Press.

The Journal of Social Change, sponsored by Walden University, welcomes manuscripts focusing on interdisciplinary research in social change that improves the human condition and moves people, groups, organizations, cultures, and society toward a more positive future.

Walden University Publishing: http://www.publishing.waldenu.edu 